16. Friederick Chopin: Collection of Articles (2000). / Editor-in-Chief Y. Yakubiak. Lviv: Spolom, [in Ukrainian].

17. Tzipin, G. (1990). Chopin and the Russian pianistic tradition. M. [in Russian].

Стаття надійщла до редакції 20.12.2017

УДК 78(477.75):008(477)](091)

DOI $10.31723 / 2524-0447-2018-26-86-98$

Тетяна Валеріївна Младенова

https://orcid.org/0000-0001-6089-6839

аспірантка Львівського національного університету імені Івана Франка, науковий співробітник музично-меморіального

музею Соломії Крушельницької

mtv_leopolis@ukr.net

\title{
ДІАЛОГІЧНІ ПРОЛЕГОМЕНИ КУЛЬТУРНОГО ЛАНДШАФТУ КРИМУ (УКРАЇНСЬКИЙ КОНТЕКСТ)
}

Мета дослідження - висвітити в культурному ландшафті Криму приклади діалогічної взаємодії між представниками різних культур та акцентувати уяву на українській складовій цього діалогу. Методологія дослідження. У статті використовуються спеціальні культурологічні методи дослідження: історично-ретроспективний (як метод культурної реконструкції), діахронічний, а також формально-логічні методи: аналіз і синтез, індукція й дедукція, абстрагування та ідеалізація. $\mathbf{H a -}$ укова новизна полягає в розгляді культурних, зокрема музичних, процесів, які відбуваються на півострові Крим, з позииіі вияву міжкультурних зв'язків. Висновки. Культура Криму презентована як багатоелементна, iї синкретичність зосереджена в фольклорі кримських татар як автохтонного етносу. Своїм східним вектором вона була особливо приваблива для митців-пілігримів. Кінець XIX - початок XX століття розглянуто як окремий період в історико-культурній хронології півострова. Особлива увага приділяється вивченню життєвих иляхів і творчості композитора О. Спендіарова та художника I. Айвазовського, чия біографія безпосередньо пов'язана як з Украӥною, так $і$ з Кримом, $і$ чий саме кримський період життєтворчості яскраво презентує комплементарність та плідність міжккультурного діалогу. У статті підкреслено вплив українського фольклору на композиторську діяльність О. Спендіарова.

Ключові слова: історико-культурний процес, музично-історичний процес, культурні контакти, діалог, полілог, синкретичність, національна музика.

(C) Младенова Т. В., 2018 
Mladenova Tetiana, PhD student of Ivan Franko National University of Lviv, Department of Philosophy and Arts

\section{Dialogical prolegomenes of the Crimean cultural landscape (cultural con- text)}

The aim of the research is to highlight examples of dialogical coexistence of different cultures in the atmosphere of cultural landscape of Crimea and to underline Ukrainian context of the dialogue. Methodology of the research: the article applies special methods of research, which correspond to the cultural analysis: historical and retrospective (as the method of cultural reconstruction) - to reproduce the stages of development of music culture in Crimea; diachronic method - to study historical factors of cultural interaction; as well as formal-logical methods: analysis and synthesis, induction and deduction, abstracting and idealization. Scientific novelty of the research is in positioning of the Peninsula culture (particularly music) as a model for a peaceful, tolerant creative dialogue. Conclusions. Culture of Crimea is presented as a multi-element phenomenon with its syncretic character accumulated in the folklore of Crimean Tatars as an indigenous ethnic group. Its eastern focus particularly attracted pilgrim artists. The work stresses some periods of life of the Crimean Armenian composer A. Spendiarov (Spendiaryan) and artist I. Aivazovsky as the representatives of Ukrainian context of the Crimean culture development. Life history and creative work of those artists is directly associated with Ukraine and Crimea. The Crimean period of their creative life brightly demonstrates complementarity and productivity of the cultural dialogue. Meet-the-artist events were a vivid proof of the assumption. A retrospective view of the meetings mentions such figures as S. Hulak-Artemovskyi, M. Starytskyi, M. Lysenko, M. Rymskyi-Korsakov, O. Hlazunov. The article argues impact of Ukrainian folklore on the activity of A. Spendiarov as a composer.

Keywords: historical and cultural process, music and historical process, cultural contacts, dialogue, polylogue, syncretic character, national music.

Младенова Татьяна Валерьевна, аспирантка Львовского национального университета имени Ивана Франко, научный сотрудник музыкально-мемориального музея Соломии Крушельницкой

\section{Диалогические пролегомены культурного ландшафта Крыма (укра- инский контекст) \\ Цель исследования - высветить в культурном ландшафте Крыма} примеры диалогического взаимодействия между представителями различных культур и акцентировать внимание на украинской составляющей этого диалога. Методология исследования. В статье используются специальные культурологические методы исследования: историко-ретроспективный (как метод культурной реконструкиии), диахронический, а также формально-логические методы: анализ и синтез, индукция и дедукиия, абстрагирование и идеализация. Научная новизна заключается в рассмотрении культурных, в частности музыкально-культурных, про- 
цессов, происходящих на полуострове Крым, с позиции выявления межкультурных связей. Выводы. Культура Крыма представлена как многоэлементная, ее синкретичность сосредоточена в фольклоре крымских татар как автохтонного этноса. Своим восточным вектором она была особенно привлекательна для художников-пилигримов. Конеи ХІХ - начало ХХ века рассмотрен как отдельный период в историко-культурной хронологии полуострова. Особенное внимание уделяется изучению жизненного пути и творчества композитора А. Спендиарова и художника И. Айвазовского, чьи биографии непосредственно связаны как с Украиной, так и с Крымом, и чей именно крымский период жизнетворчества презентует комплементарность и плодотворность межкультурного диалога. В статье подчеркнуто влияние украинского фольклора на композиторскую деятельность А. Спендиарова.

Ключевые слова: историко-культурный процесс, музыкально-исторический процесс, культурные контакты, диалог, полилог, синкретичность, национальная музыка.

Актуальність теми. Невід’ємною складовою історико-культурного процесу протягом багатьох століть в нашій державі були і залишаються етнічні контакти, особливе місце у яких належить Криму. В світлі сьогоднішніх реалій вкрай необхідно зберігати півострів в українському культурному просторі, залучаючи історичні факти контактного діалогу. Якими були ті контакти всередині Криму, а також із суміжними територіями? Біографічні сторінки яких митців Криму можуть презентувати український контекст розвитку кримської культури?

Частково відповіді на ці запитання можемо знайти в сучасних дослідженнях, вивчаючи, наприклад, сходознавчі праці Я. Дашкевича, у яких розглянуто особливості українсько-кримськотатарських відносин, починаючи з періоду кримського середньовіччя, або аналізуючи літературні та музичні тексти пісенного фольклору українців і кримських татар. Так, О. Чернишева у дослідженні «Тюрко-українські фольклорні зв'язки в пісенній творчості» розкриває генетичний аспект контактного діалогу; історія музичної культури кримського ханства висвітлена Н. Абдульваапом у передмові до нотної збірки Дж. Карікова «Кримськотатарська інструментальна музика ханського періоду»; окремі сторінки багатонаціональної культури півострова розглянуто в роботі С. Ізідінової «Національна музика кримських татар». Але деякі аспекти культурної взаємодії, що пов’язані з музичною культурою Криму, залишаються поза увагою. Проблема може бути вирішена завдяки систематизації документальних фактів кон- 
тактного діалогу, які збереглися в автобіографічних джерелах (спогадах, листуваннях, т. ін.). Мета дослідження полягає у висвітленні в культурному ландшафті Криму прикладів діалогічної взаємодії між представниками різних культур та акцентуванні уваги на українській складовій цього діалогу. Осмислюючи питання національної та регіональної ідентифікації Криму, проблему вибору майбутнього, необхідно звернутися до прикладів та уроків минулого в музично-історичному процесі. Наукова новизна полягає в розгляді культурних, зокрема музичних, процесів, які відбуваються на півострові Крим, з позиції вияву міжкультурних зв'язків.

Виклад основного матеріалу. Доля Криму в історико-культурному плані є прикладом того, як взаємодія на його території різних цивілізацій, народів, релігій і укладів життя призвела до утворення синкретичної культури, значення якої для географічно сусідніх територій було таким же великим, як, скажімо, значення аль-Андалусу в Іспанії на Заході Європи [6]. Крим, який знаходиться на перетині торгових шляхів, що об'єднують Причорномор'я з Середземномор'ям, і який лежить на караванному шляху до Індії та Китаю, завжди опинявся в сфері етноміграційних процесів. Зручне географічне розташування, добрі кліматичні умови з давніх часів сприяли осіданню прибулих народів. В результаті такого осідання сформувався етнос, який складається зі скифо-греко-гунно-гото-хазаро-булгаро-кипчакських елементів. Багатоманітність етнічних компонентів відбилась на формуванні автохтонного населення півострова, його мови та культури. Багатовікову пам'ять про одну з найбільш унікальних культур зберігає національна музика кримських татар.

Основним джерелом музичної творчості в Криму завжди була i залишається народна пісня, яка протягом багатьох століть зберігалась в усній традиції. Численні мандрівники, які відвідували півострів у різні історичні періоди, відзначали велику любов кримчан, кримських татар зокрема, до пісенної творчості. Одним з проявів цієї схильності стала поява в народному середовищі талановитих виконавців - імпровізаторів (ашик'лар, кедайлар, чалг'иджилар, йирджилар, усталар), різножанрове мистецтво яких переживало свій розквіт в часи кримського середньовіччя. У палацах і резиденціях хана, султана, у маєтках феодалів жили і творили поети, співаки (муг'ані), музиканти-виконавці не тільки з Криму, підвладних територій і сусідніх країн, а й з країн Європи, Середземномор'я (Італія, Греція, Балкани) і Сходу (Єгипет, Іран, Туреччина, Кавказ, Середня 
Азія). Музика середньовічного Криму нагадує то класичну музику Туреччини, Ірану, Закавказзя, яку в свою чергу не оминула впливом арабська музична культура, то грецькі «трагуді», «хорони» й італійські і генуезькі канцонети.

При вирішальній ролі філософії і традицій ісламу на духовну атмосферу й економічне життя Криму постійно впливали імпульси, які виходили від не мусульманських меншин півострова, а також від географічно близьких територій. Незважаючи на не завжди мирні відносини з сусідами і внутрішні чвари, для мешканців Криму були властиві терпимість до інших спільнот. Протягом багатьох століть на кримській землі мирно співіснували ханська соборна мечеть, православний скит і церква, караїмська кенаса і кримчакська синагога і мідраш, григоріанська вірменська церква. Завдяки цьому багато $є$ спільного в походженні, фольклорі, заняттях, побуті, обрядах, традиціях і, як наслідок, єдина музична культура. До недавнього часу майже всі етнічні групи Криму (греки, караїми, кримчаки, вірмени) вважали більшість пісень і танців кримських татар своїми, співали і танцювали під їх мелодії. Адже до XIX століття загальнокримською мовою була кримськотатарська, пісні звучали виключно кримськотатарською мовою. Зберіглася згадка караїма Б. Кокеная про музичне оформлення свята к’оншума: «... в тиші ночі по слобідці караїмів було чутно глухий гуркіт турецького великого барабана. ... людей п’ять-вісім, інколи десять татар становили оркестр з зурни, бубна-даре, скрипки, іноді одного мідного духового інструменту, флейти і обов'язково давула. Грали звичайно без нот. Але ніхто з учасників цього к’оншума, будь він караїм, грек, татарин, кримчак або вірменин, не проміняв би звуків цього дикого оркестру на звуки симфонічного або іншого європейського оркестру...» (тут і далі переклад наш. - T. M.) [7].

Перед нами чудовий приклад культурного діалогу, полілогу, коли традиційні свята народів Криму стають відображенням мирного співіснування, співтворчості і, таким чином, духовного єднання у спільному творчому процесі. У наведеній цитаті є порівняння з європейським оркестром. Свого часу, як відомо, європейський оркестровий склад зазнав значного впливу з боку так званого «мехтер-музикаси» - османського воєнного оркестру, що існував і при дворі кримських ханів. В європейській музичній культурі виникає цілий напрямок - Janitcharenmusik (яничарська музика), на рубежі XVII-XVIII століть в Європі з'явився цілий ряд ударних інструментів. Великий барабан, тарілки використовувались для посилення ритмічної осно- 
ви європейського оркестру, тембри дзвіночків, трикутників імітували звучання турецького чевгене. Орієнтальні тюркізми органічно урізноманітнили темброву палітру творів віденських класиків.

Завдяки сучасним дослідженням можна з упевненістю констатувати, що кримськотатарська музична класика, як виконавська, так і композиторська, починається задовго до XX століття. Вона має тривалу історію розвитку, що йде своїм корінням в епоху Кримського Ханства. Придворну музику періоду османського (турецького) протекторату над Кримом сучасні дослідники називають класичною музикою кримського середньовіччя. До останнього часу інформація про неї залишалась практично невідомою. Музична спадщина кримського хана Газі Герая (1554-1607 pp.), а також інших членів правлячої династії була дбайливо збережена в різних приватних та державних колекціях Туреччини. Твори Газі Герая вивчаються і виконуються на курсах турецької класичної музики в консерваторіях. Збереглися більше 70 його творів для танбура - східного струнного віртуозного музичного інструмента, яким Газі Герай, за свідченням сучасників, чудово володів. В ханському палаці, в Бахчисараї панувала жвава творча атмосфера. Він був центром розвитку кримськотатарської класичної музичної культури. В часи правління Крим-Герая бахчисарайський палац був осередком муз та науки. Хан оточував себе освіченими митцями, через яких він долучався до європейського, а саме французького мистецтва. 3 драматичного жанру Герай найбільше любив французьку комедію, особливо Мольєра [1].

Процес фіксації і вивчення кримського фольклору, у тому числі й музичного, почався доволі пізно, лише у XX столітті. До цього свідоцтва музичного фону кримського півострова зустрічаються вкрай рідко. Так, наприклад, в «Нарисах Криму» популярного письменника Е. Маркова, який подорожував по Криму з кінця 60-х років XIX століття, ми знаходимо поетичні рядки про пісню чатирдагського чабана, який грає на тулуп-зурні (кримськотатарська волинка): «...я вперше почув добре заспівану татарську пісню. У ній багато принади... головне багатство в ії̈ коротких, ніжних трелях, в якомусь невпинному тремтінні, підніманні і спаданні голосу... дудки тут солісти, хутро - хор... Але ні принадність пісні, ні мистецтво музиканта, ні оригінальність гри не можуть пояснити тієї повноти насолоди, яку відчував я, слухаючи спів чабана. Хвилина була тут все» $[9,243]$. Настільки емоційними сприймаються ці спогади, що пісня чабана ніби створює відчуття поєднання з навколишньою природою, з аро- 
матом повітря, у якому майорять пахощі чебрецю і полину, з химерним малюнком скель, що оточують тихі кримські бухти.

Звертаючись до документальних свідчень, спогадів, листів, які пов'язані з творчим світом Криму кінця XIX - початку XX століть, зрозуміємо, що саме в цей період починається історія нового часу в культурно-історичній хронології півострова. Російська анексія змінює геополітичний вектор, який в майбутньому приносить негативні для культури Криму наслідки (про які пишуть М. Римський-Корсаков, А. Чехов, цікавий приклад елементів абсурду псевдокультурного розвитку музично-театрального мистецтва Криму ми знаходимо в спогадах Остапа Вишні «Кримські усмішки»).

В мистецькому світі ще впродовж тривалого часу Крим сприймається як «Схід в мініатюрі» (А. Міцкевич), а поліетнічний простір півострова рефлексивно залишається прикладом гармонійного, комплементарного діалогу, полілогу різних культурних традицій. Про це свідчить творчість як пілігримів, так і представників мистецького світу самого півострова. 3 цього часу змінюється географія культурних столиць, точніше, відбувається розосередження. Ханський Бахчисарай «поступається» місцем Ялті, Феодосії, пізніше Сімферополю.

Поряд з геополітичним фактором в Росії мало місце поширення ідей європейського просвітництва та романтизму, що тягне за собою потоки переказів з французької орієнтальної літератури. У зв’язку з такою неоднозначною зацікавленістю Сходом в 1845 році у Петербурзі було засновано Російське імператорське географічне товариство. Рубіж XIX-XX століть представляє цілий ряд імен вчених сходознавців, дослідників - діячів культури, які дбайливо ставилися до культурної спадщини стародавніх цивілізацій півострова. Так, значна роль у вивченні, популяризації кримськотатарського музичного фольклору належить російському професорові - історику В. Смирнову, польському музиканту - етнографу А. К. Кончевському, видатному кримськотатарському просвітителю Ісмаїл беку Гаспринському, в 20-30-ті роки - кримським, кримськотатарським музикантампрофесіоналам, більшість яких пройшли через депортацію: Асану Рефатову, Яг’я Шерфетдінову, Варварі Ханджібековой, Ільясу Бахшишу.

У числі перших збирачів кримського фольклору, які відвідали Крим, - професійний етнограф, згодом автор збірок «Пісні Криму» (1923 р.) та «Наспіви Сходу» (1925 р.), а також книги «Казки, легенди і перекази Криму» (1930р.) - Аркадій Карлович Кончевський (за 
походженням - поляк). 3 його спогадів: «...на перших порах багато моїх нових друзів - кримських татар мене не розуміли і цуралися... 3 великими труднощами і наполегливістю вдалося їх привернули до себе: поступово засвоїв багато татарських слів, виразів, навчився грати на національних музичних інструментах... після чого мусульмани - кримські татари почали довіряти мені - поляку-католику...» $[6,11]$.

Неповторні природні ландшафти півострова, їх симфонічне поєднання з прикрасами стародавніх архітектурних пам'яток та музично-поетичним фольклором кримського Сходу, надихали пілігримів Криму та насичували їх твори орієнтально-імпресіоністичними барвами. Цілюще повітря, мальовничі краєвиди на тлі моря і гір ставали натхненням, музикою, що звучала в душі художника, який вперше ступив на цю прекрасну землю. Саме Крим перетворить музичного історика-драматурга М. Мусоргського на майстра інструментального живопису, який малює красу південного узбережжя в своїх фортепіанних мініатюрах «Байдари» $\mathrm{i}$ «Урзуф біля Аю-Дага». Художньо забарвлені спогади композитора можуть бути епіграфом до цих творів: «Точно чудесный сон припоминается южный берег Крыма - то грозный и недоступный, то нежный и приветливый, с роскошнейшими садами, прелестными постройками, одетыми сверху донизу во вьющиеся редкостные растения, легкие резные карнизы крыш с кружевными галереями и балконами, при всем этом ярко-синее небо и зеленое, будто изумрудное море» $[11,96]$.

Гостював в Феодосії у відомого художника-мариніста I. Айвазовського і засновник російської музичної класики М. Глінка. Причому саме художник знайомив композитора 3 кримськими татарськими наспівами, награвав їх, користуючись власними нотними записами. Згодом композитор використає музично-ритмічні формули цих мелодій в опері «Руслан і Людмила». Опера О. Бородіна «Князь Ігор» отримала світове визнання завдяки половецьким сценам, основа яких - музичні мотиви, що були зафіксовані під час мусульманського свята рамазан в Сімферополі, Бахчисараї, Євпаторії. Саме в Криму у 1887 році створив свої перші опуси тоді ще юний піаніст С. Рахманінов. А вже в 1900 році, милуючись красою Аю-Дага, він почне працювати над партитурою другого фортепіанного концерту, головна харизма якого безсумнівно прихована в лірико-орієнтальних темах.

Чарівна, східна за колоритом симфонічна сюїта «Шехерезада» була складена М. Римським-Корсаковим у 1888 році. До цього ком- 
позитор вже двічі відвідував Крим (у 1874, 1881 роках), і орієнтальні, натхненні кримськотатарським музичним фольклором (як зазначав сам композитор) сцени прикрасили весняну слов'янську оперу-казку «Снігуронька», а згодом і оперу-билину «Садко». Сольні імпровізації скрипки, кларнета в симфонічних формах «Антар», «Шехеразада», а також в оперних інструментальних картинах, своїм ладовим колоритом, орнаментальним візерунком відтворюють звучання ідентичних східних інструментів (к’авал, кеманча), які на той час були поширені на Кримському півострові [10].

У Таврійську область Росії входила частина південної України. Саме через неї здійснюють «паломництво» в Крим представники мистецького світу Росії, України та суміжних територій. Таврійська область (надалі - губернія) охоплювала (аж до 1917 року) не тільки півострів, а й три великих повіту прилеглої України, заселених майже виключно українцями. Як зазначає Я. Дашкевич: «В період існування Новоросійського генерал-губернаторства Крим взагалі опинився в «українському оточенні»: до складу генерал-губернаторства увійшли, крім Таврійської, також Херсонська і Катеринославська губернії, у свій час (по 1842 рік) також Кубань - область Чорноморського війська» $[5,395]$.

Серед діячів культури Кримського півострова, чия біографія пов'язана з Україною, слід згадати митців вірменського походження. Один з них, кримський вірменський композитор Олександр Спендіаров належить до перших етнографів - знавців кримського музичного фольклору. Серед старих нот майстра зберігся альбом записів поширених в той час в Криму побутових мелодій: татарських, вірменських, болгарських, грецьких, російських, а також пісень українських співців-лірників. За спогадами сестри композитора - Марії - українські пісні він з зацікавленістю слухав і нотував, коли виїжджав з Сімферополя на літні канікули в село Каховка (там композитор народився). Ще один дуже цікавий факт, який наводить Марія Спендіарова, постановка опери С. Гулака-Артемовського «Запорожець за Дунаєм» учнями 1-ї гімназії в роки навчання там Олександра. Опера в той час була дуже популярна в Сімферополі після гастролей українського Театру корифеїв. Українське драматичне мистецтво, яке було репрезентовано на кримських сценах, знайшло свого вдячного глядача. Відомо, що у Таврійській губернії творчий колектив М. Старицького кілька сезонів виступав із шаленим успіхом. Про високий рівень майстерності українських акторів трупи М. Старицького у Криму писала 
навіть російсько-татарська газета «Переводчик-Терджиман», основною темою якої було життя мусульманської громади. Таким чином, про особливості «малороссийских пьес» були сповіщені й численні тюркомовні читачі цього видання [2].

Якщо вибудовувати ієрархію фольклорного матеріалу в творчості Олександра Спендіарова, слід відмітити, що композитор віддає перевагу східним елементам: «Это особая манера восточной музыки наслаждение певца и музыканта звуком, переливами, затейливыми украшениями-фрагментами. Они как фантастические и нежные, ажурные, тонкие фрески древних зданий» $[13,68]$. В партитуру оркестрової сюїти «Кримські ескізи» органічно вплетені кримськотатарські народні мотиви, з їх східним мелосом, танцювальними ритмоінтонаціями, дуже спорідненими з вірменською народною музикою. Сюїта неодноразово звучала на концертних сценах Росії, була презентована в Німеччині, Італії, Франції, Данії, Америці, Польщі, Фінляндіï. За порадою свого вчителя М. Римського-Корсакова О. Спендіаров почав роботу над оперою «Бахчисарайський фонтан». Пам’ятник архітектури пізнього середньовіччя Криму, оспіваний О. Пушкіним, стає джерелом натхнення для багатьох митців. Мотиви легенди поетизовані в кримських сонетах Адама Міцкевича («Бахчисарай») і Лесі Українки («Бахчисарайська гробниця»). Історія кохання Крим-Гірая і Діляри Бікеч надихнула на створення музично-театральних композицій А. Аренського, Б. Асаф’єва, А. Караманова та ін.

Повертаючись до фольклорних пріоритетів О. Спендіарова, зазначимо, що серед його опусів друге почесне місце займають обробки українських народних пісень, це солоспіви: «Чи ти, милий, пилом припав», «Ніхто ж не винен», «Ой, не світи, місяченьку», «Час додому, час», «Коли б мене, господи», «Як поїхав мій миленький»; вокальні дуети в супроводі фортепіано: «Ой, йшов я вулицею», «Добрий вечір, дівчино», «Сидить дід на печі», «Лугом іду, коня веду», «Хіба ж я тобі не казала». Доповнюють цю ретроспективу «Українська сюїта» («Ой, наступила та чорна хмара», «За тучами, за хмарами», «Ой, летіла горлиця», «А вже весна, а вже красна») для 4-голосного хору a'capella з оркестром, «Заповіт» на слова Т. Шевченка.

Талант О. Спендіарова ще в роки навчання в сімферопольській гімназії помітив відомий художник-мариніст I. Айвазовський. 3 часом вони стають не тільки друзями, але й родичами (Спендіаров одружився з племінницею Айвазовського). Предки Айвазовського були 3 галицьких вірмен, що переселилися в Галичину з турецької Вірменії у 
XVIII столітті. Відомо, шо його родичі володіли великою земельною власністю у Львові, проте ніяких більш детальних документальних свідчень про цей період з життя Айвазовських не збереглося. Його батько Костянтин (Геворг) і після переселення до Феодосії писав прізвище на польський манер - Гайвазовський (полонізована форма вірменського прізвища Айвазян). Сам Айвазовський в автобіографії говорить про батька, що той через сварки зі своїми братами в юності переселився з Галичини в Дунайські князівства (Молдавію, Валахію) де зайнявся торгівлею, звідти переїхав в Крим, в Феодосію. Прижиттєві публікації, присвячені Айвазовському, з його слів передають сімейні спогади про те, що серед його предків були також і турки. Автор твору «Повесть о художнике Айвазовском» Лев Вагнер, спираючись на сімейні спогади Айвазовських, художньо відтворює картину музичного фону Феодосії часів дитинства Ованеса (Івана), в якій слідом за піснями, що лунали з турецьких галер, звучав ліричний спів бандуристів, прибулих в Крим з чумаками. 3 репертуару кримських музикантів-рапсодів згадуються українські народні танцювальні пісні, серед яких найпопулярніша - «Гоп, мої гречаники»: «Мальчики и сам Константин Гайвазовский подпевали певцу и притопывали в такт ногами, а Ованес сорвался со своего места и завертелся, уморительно подпрыгивая и напевая...» [4].

Символічно, що помешкання обох митців Криму, О. Спендіарова (будинок-палаццо в грецькому стилі в Ялті) та І. Айвазовського в Феодосії (художня майстерня), стають в той період культурними осередками, концертними та театральними камерними сценами. В музеї І. Айвазовського зберігся автограф М. Лисенка, який відвідував Крим у 1886 році. В тому ж році російський композитор О. Глазунов в листі М. Римському-Корсакову, після зустрічі на теренах півострова 3 українським класиком, напише: «Он меня тронул тем благоговением и благодарностью, с которыми он говорил о Вас» [3, 69]. На жаль, не збереглися детальні документальні свідчення перебування М. Лисенка в Криму, але існує факт, який засвідчує зацікавленість композитора в особливостях музичного інструментарію кримських татар. В одному з досліджень композитор зазначає, що «бжура татар чорноморських» (кримськотатарська бжура - різновид саза) має пряму схожість з українською кобзою [8].

Висновки. Культура Криму є багатоелементною та особливо приваблива для митців-пілігримів своїм східним вектором. Життєві шляхи і творчість композитора О. Спендіарова та художника I. Ай- 
вазовського безпосередньо пов'язані як з Україною, так і з Кримом, а кримський період їхньої життєтворчості яскраво презентує комплементарність та плідність міжкультурного діалогу.

Відторгнення півострова від материкової України тягне за собою культурну ізоляцію суміжних територій, які мають давню історію мирного, толерантного творчого співіснування. Реалії сьогоднішнього життя з численними трагічними подіями, що відбуваються через суперечності на геополітичному, національному, релігійному грунті, в черговий раз свідчать про те, як багато люди страждають, які несуть непоправні втрати в результаті конфліктів. Унеможливити явища, що призводять до знищення духовних цінностей, до людських жертв, можуть допомогти численні приклади гармонійного співіснування. Окремі сторінки багатовікової історії культурних контактів підтверджують те, що тільки за умов толерантної взаємодії здійснюється культурне взаємозбагачення, формується духовна єдність, яка є основою для самозбереження людства.

\section{СПИСОК ЛІТЕРАТУРИ}

1. Абдульваап Н. Предисловие. Крымскотатарская инструментальная музыка Ханского периода / ред.-сост. Дж. Кариков. Симферополь: Доля, 2007. C. $5-10$.

2. Ганкевич В., Шендрікова С. Театральна трупа М. Старицького у КриMy. URL: http://dspace.nbuv.gov.ua/bitstream/handle/123456789/74200/57Gankevich.pdf/ (дата звернення: 13.09.2017).

3. Гозенпуд А. Н. В. Лысенко и русская музыкальная культура. Москва: Музгиз, 1954. $153 \mathrm{c}$.

4. Вагнер Л. Повесть о художнике Айвазовском. URL: https://www.litmir. $\mathrm{me} / \mathrm{br} / \mathrm{p}=112526 \& \mathrm{p}=3 /$ (дата обращения: 13.09.2017).

5. Дашкевич Я. Україна і Схід / упоряд. Г. Сварник, А. Фелонюк; НАН України. Інститут української археографії та джерелознавства ім. М. С. Грушевського. Львівське відділення; Львівський національний університет імені Івана Франка. Львів: 2016. 960 с.

6. Изидинова С. Р. О национальной музыке крымских татар. Севастополь: Изд-во СО «ЭКОСИ - Гидрофизика», 1995. 45 с.

7. Йырлар. Песни. URL: http://karai.crimea.ua/390-jjyrlar.-pesni.html/ (дата обращения: 19.05.2018).

8. Лисенко М. В. Характеристика музичних особливостей українських дум і пісень у виконанні кобзаря Вересая. К., 1978. 95 с.

9. Марков Е. Очерки Крыма. Симферополь: Таврия, 1995. 543 с.

10. Младенова Т. Семантика Востока в симфонических картинах Н. А. Римского-Корсакова. Культура народов Причерноморья. 2011. № 217. С. 136-139. 
11. Модест Петрович Мусоргский / сост. Р. К. Ширинян. Москва: Музыка, 1989. 192 с.

12. Спендиарова М. Спендиаров. URL: http://www.e-reading.org.ua/ bookreader.php/1001363/ (дата обращения: 13.09.2017).

13. Спендиаров о музыке / сост.-ред. В. Бальян. Ереван: Изд-во ЦК КП, 1971. $116 \mathrm{c}$.

\section{REFERENCES}

1. Abdulvaap, N. (2007). Crimean Tatar instrumental music of Khanate period. Preface. Simferopol: Dolia [in Russian].

2. Gankevych, V., Shendrikova, S. The theater troupe of M. Staritsky in the Crimea. Retrieved from http://dspace.nbuv.gov.ua/bitstream/handle/123456789/74200/57-Gankevich.pdf/ [in Russian].

3. Gozenpud, A. (1954). N. V. Lysenko and Russian music literature. Moscow: Muzgiz [in Russian].

4. Vagner, L. A tale about artist Aivazovsky. Retrieved from https://www.litmir. $\mathrm{me} / \mathrm{br} / ? \mathrm{~b}=112526 \& \mathrm{p}=3 /$ [in Russian].

5. Dashkevych, Ya. (2016). Ukraine and the East. Lviv [in Ukrainian].

6. Izidinova, S. R. (1995). About national music of Crimean Tatars. Simferopol: EKOSI - Gidrofizik [in Russian].

7. Yyrlar. Songs. Retrieved from http://karai.crimea.ua/390-jjyrlar.-pesni.html/ [in Russian].

8. Lysenko, M. V. (1978). Characteristics of musical features of Ukrainian dumas and songs performed by Veresay kobzar. K. [in Ukrainian].

9. Markov, E. (1995). Essays about Crimea. Simferopol: Tavria [in Russian].

10. Mladlenova, T. (2011). Semantics of the East in symphonic pictures of N. A. Rymskyi-Korsakov. Culture of the nations of Black Sea area, 217 [in Russian].

11. Shirinian, R. K. (Eds.). (1989). Modest Petrovych Musorhsky. Moscow: Muzyka [in Russian].

12. Spendiarova, M. Spendiarov. Retrieved from http://www.e-reading.org.ua/ bookreader.php/1001363/ [in Russian].

13. Balian, V. (Eds.). (1971). Spendiarov about music. Erevan: TsK KP [in Russian].

Стаття надійщла до редакції 22.11.2017 